\title{
Core Histone Macro-H2A
}

National Cancer Institute

\section{Source}

National Cancer Institute. Core Histone Macro-H2A. NCI Thesaurus. Code C95407.

A histone protein that is comprised of a histone H2A domain, which allows interaction

with the nucleosome, and a macro domain, which may bind to ADP-ribose. This protein

can substitute for histone $\mathrm{H} 2 \mathrm{~A}$ in the nucleosomal complex and plays a role in transcriptional repression and $\mathrm{X}$ chromosome inactivation. 